\title{
Sociodemographic profile, family aspects, perception of health, functional capacity and depression in institutionalized elderly persons from the north coastal region of Rio Grande do Sul, Brazil
}

Jucélia Fátima da Silva Güths' Maria Helena Vianna Metello Jacob² Ana Maria Pujol Vieira dos Santos² Guilherme Anziliero Arossi² Jorge Umberto Béria ${ }^{2}$

Abstract

Objective: to describe sociodemographic and family relationships, health status, depression and degree of functional capacity in institutionalized elderly persons in eleven long-term care facilities for the elderly in the north coastal region of Rio Grande do Sul, Brazil. Methods: a cross-sectional study was carried out of 60 institutionalized elderly persons without cognitive impairment, confirmed by a score greater than 13 in the Mini Mental State Exam. Questionnaires were used to obtain data on sociodemographic conditions, family relationships, and self-perception of health. Functional capacity was evaluated with the Barthel Index and the Geriatric Depression Scale was applied. Results: A predominance of women, widowed and single, with a of low level of education and precarious financial status, most of whom who did not have children, was observed. The elderly persons complained about difficulty walking (38.3\%), generalized pain $(16.7 \%)$

Keywords: Elderly. Depression. Homes for the Aged. Geriatric Nursing. Functional Capacity. and vision problems $(13.3 \%)$. The majority $(95 \%)$ reported suffering from two to three chronic diseases and making daily use of three or more drugs. Although 55\% of the participants presented depressive symptoms and morbidity, they reported functional independence and 50\% rated their health as good. Conclusions: These data contributed to the knowledge of the health status and functional capacity of these institutionalized elderly persons, aiming to improve the care provided to this public.

\footnotetext{
Universidade Luterana do Brasil, Curso de Fisioterapia. Torres, RS, Brasil

2 Universidade Luterana do Brasil, Programa de Pós-Graduação em Promoção da Saúde. Canoas, RS, Brasil 


\section{INTRODUCTION}

The rapid growth of the elderly population is the subject of discussion around the world. In Brazil, this interest arose as a result of the significant increase in the life expectancy of the elderly population, caused by technological advances in the area of health and a decline in fertility rates ${ }^{1}$. In addition, there is a perceptible lack of preparedness among society and family members to face the challenges of this new reality, resulting in a growing demand for long-term care facilities for the elderly (LTCFs).

LTCFs are defined as residential institutions, both governmental and non-governmental, intended for the collective housing of persons aged 60 or over, who may either have or not have family support. Regardless of the negative and prejudiced idea that people have about LTCFs, they can represent a possible alternative for many elderly people and their families².

The manner in which the elderly live in institutions, the quality of the last years of life and their most significant limitations can be observed through studies directed at this age group. It has been observed that there are few such studies in this area in Brazil, and that most of those that do exist reflect the profile of this population in large centers ${ }^{3}$, involving populations with different habits and characteristics to the populations of small municipal districts.

The self-perception of the health of the elderly presents contradictory findings in literature. One study identified that the majority of elderly persons in an LTCF in Minas Gerais considered their health as poor or very poor ${ }^{4}$; while other studies in Passo Fundo (Rio Grande do Sul) ${ }^{5}$ and Guarapuava (Paraná) ${ }^{6}$ showed that the majority of the elderly interviewed considered their health to be good or excellent. These contrasting results create the need to investigate the profile of the institutionalized elderly in different regions of Brazil, since economic profile and the practicing of physical activity influence the self-perception of health of these elderly people?.

In addition to the heterogeneity of the perception of health of the elderly in the different regions of Brazil, a profile of frailty has been identified in relation to the functional capacity of elderly persons, who were dependent in the performance of daily activities ${ }^{8}$, while some studies have found that elderly from LTCFs who did not suffer cognitive deficiency were, for the most part, functionally independent ${ }^{9,10}$. Therefore, identifying the profile of the institutionalized elderly in different regions can contribute to the creation of public policies that are more suitable for individual needs, with a view to improving the quality of life of these populations.

Functional capacity has been described as a predictor of depressive symptoms among institutionalized elderly persons, with functional limitations as an indicator of depressive symptomatology among the same ${ }^{11}$. There are reports in literature of depression affecting from $48 \%$ to $60 \%$ of institutionalized elderly people ${ }^{12-15}$. Another study indicates that the fact that these elderly people live alone, are widowed and institutionalized appears to contribute in an evident manner to the presence of depressive symptoms ${ }^{16}$.

Literature regarding the profile of institutionalized elderly persons usually addresses the populations of medium and large cities, which are quite different from the north coast of the state of Rio Grande do Sul. This area comprises 23 small municipal districts, which since 2000 have grown at a greater rate than the state as a whole, despite the low economic development levels of the region. The LTCFs present in this area serve a heterogeneous population, the profile of which should be characterized to allow the creation of specific public policies, and justifying the undertaking of this cross-sectional descriptive study.

The aim of the present study is to identify the socio-demographic profile and family characteristics of institutionalized elderly persons in the north coast region of the state of Rio Grande do Sul, as well as their perception of self-reported health, functional limitations and depression.

\section{METHOD}

A descriptive study, involving elderly people aged 60 years or older residing in 11 public and private LTCFs in the north coast of the state of 
Rio Grande do Sul, was undertaken. Data collection was carried out between July and October of 2010 in eight municipal districts: Torres, Três Cachoeiras, Capão da Canoa, Tramandaí, Osório, Cidreira, Santo Antônio da Patrulha and Mostardas.

The study population corresponded to 218 institutionalized elderly persons. When the exclusion criteria were applied, 13 elderly people said they were not interested in participating; 24 were bedridden, with significant clinical sequelae; 12 had Severe Psychiatric Disorders, as verified in the medical records available at the LTCF; nine were under the age of 60; three had severe auditory impairment; and four were hospitalized.

In order to evaluate if the participants were sufficiently cognitive to participate in the research, the Mini Mental State Exam (MMSE)17 was applied to the 153 elderly subjects in interview form. The elderly persons answered questions that assessed the presence or absence of cognitive disorders, such as temporal and spatial orientation, registration, immediate memory, calculation and language (aphasia and constructional ability were assessed). According to Bertolucci et al.,17 the absence of cognitive disorder is indicated by the following values: 13 points for illiterates; 18 points for individuals with 1 to 7 years of schooling and 26 points for those with 8 years or more of schooling.

After applying the MMSE, 93 elderly people did not reach the minimum score (13 points) 9 . Thus, the results of this research are based on the analysis of 60 institutionalized elderly persons.

The following instruments were used to collect data: the Barthel Index Sociodemographic Questionnaire18 and the reduced version of the Geriatric Depression Scale (GDS-15)19. The sociodemographic questionnaire covered various issues related to sociodemographic factors, the characteristics of the institution, length of stay, family ties, general health conditions and the selfperception of health described by the elderly, classifying their health at the moment of the study as: excellent, good, fair, and poor20.

The Barthel Index, an instrument validated in Brazil18, is a questionnaire used to verify the functional capacity of individuals. The protocol comprises ten questions about feeding oneself, transfers, grooming, toilet use, walking on a flat surface, climbing stairs, dressing and control of the anal and bladder sphincters. The total result ranges from 0 to 100 points, ranging from dependent to independent.

One of the most commonly used methods for identifying depressive symptoms in the elderly is the GDS14. The reliability of the Brazilian version of the GDS-15 items has been proven, and it has been found to be a relatively stable indicator for the detection of cases of depression in the elderly and the monitoring of the severity of their symptoms19. It is an instrument with 15 questions, in a reduced and simplified form, referring to the mood and state of health. The cutoff points vary, with 0 to 5 considered a normal state; from 5 to 10 moderate depression; and above 10 points, severe depression.

The qualitative variables were described in simple and relative frequencies while mean and standard deviation or median were used for the quantitative variables. All the instruments used in the method were applied by the same researcher.

The present study was approved by the Research in Human Beings Ethics Committee of the Universidade Luterana do Brasil (the Lutheran University of Brazil) ( $\mathrm{n}^{\circ} 2010-161 \mathrm{H}$ ), with the ethical rights of those interviewed guaranteed in accordance with Resolution 466/12. The elderly persons received detailed information about the study and each signed a Free and Informed Consent Form (FICF).

\section{RESULTS}

Of the 60 institutionalized elderly participants in the study, 66.7\% were female. The elderly persons were predominantly aged between 70 and 79 years (36.7\%), had an incomplete elementary education (35\%), were widows (46.7\%) and white/Caucasian (95\%). They worked in agriculture (42\%), were from the Rio Grande do Sul countryside (50\%) and reported having a monthly income of between one and two monthly minimum wages (48.3\%) (Table 1$)$. 
Table 1. Sociodemographic profile of elderly residents of Long Term Care Facilities in eight municipal districts (Torres. Três Cachoeiras. Capão da Canoa. Tramandaí. Osório. Cidreira. Santo Antônio da Patrulha and Mostardas) of the north coast of Rio Grande do Sul. Rio Grande do Sul. 2010.

\begin{tabular}{ll}
\hline Variables & $\mathrm{n}(\%)$ \\
\hline Gender & \\
Female & $40(66.7)$ \\
Male & $20(33.3)$ \\
\hline Age range (years) & \\
60 to 69 & $15(25.0)$ \\
70 to 79 & $22(36.7)$ \\
80 to 89 & $20(33.3)$ \\
90 or more & $03(5.0)$ \\
\hline
\end{tabular}

Schooling

Illiterate

$10(16.7)$

Elementary School - Early Years-Incomplete

$21(35.0)$

Elementary School - Early Years-Complete

$12(20.0)$

Elementary School - Final Years-Incomplete

$01(1.7)$

Elementary School - Final Years-Complete

$05(8.3)$

Incomplete High School

$03(5.0)$

Complete High School

$05(8.3)$

Incomplete Higher Education

$03(5.0)$

Marital status

Widowed

$28(46.7)$

Single

19 (31.6)

Separated / Divorced

$10(16.7)$

Married

$03(5.0)$

Skin color/ethnicity

White/Caucasian

$57(95.0)$

Brown/Mixed-Race

$03(5.0)$

Nationality

Countryside of state (Rio Grande do Sul)

$30(50.0)$

Metropolitan Area

$15(25.0)$

Porto Alegre. Rio Grande do Sul

$09(15.0)$

Other states

$03(5.0)$

Other countries

$03(5.0)$

Occupation

Agricultural worker

$26(42.0)$

Housewife

14 (23.4)

Industrial worker

$03(5.0)$

Domestic worker

$03(5.0)$

Technical-administrative role

$02(3.3)$

Professional

$02(3.3)$

Others

$10(18.0)$

Monthly income (minimum salary)

One or less

1 to 2

$29(48.3)$

3 to 5

07 (11.7)

Over 5

01 (1.7)

No income 
The median stay at the institution was 18 months, with $35 \%$ of the elderly persons residing in the facilities for up to nine months, $40 \%$ between nine and 35.6 months and 25\% having over 35.6 months of institutionalization.

The family aspects of the elderly persons are presented in Table 2. In terms of parenting, 36.7\% had children, all of whom were visited by their sons or daughters. The majority of the elderly participants $(75 \%)$ received other visits.

In terms of the main health complaint reported, the majority reported difficulty walking, followed by generalized pain and vision problems. Regarding the perception of general health status, compared to that of another person of the same condition and age group, half of the sample described their health as good. Only $25 \%$ of the elderly persons had health insurance (Table 3).

The vast majority of participants reported having at least two to three diseases, with Systemic Arterial Hypertension, Type II Diabetes Mellitus and Osteoarthrosis the most frequently cited. The vast majority of the sample used medications on a daily basis, ingesting three or more types on average (Table 3).
The functional capacity of the elderly evaluated by the Barthel Index varied from 65 to 100 points, with the majority being considered functionally independent (Table 4).

The GDS- 15 revealed that $53 \%$ of the elderly persons exhibited symptoms of moderate depression while one elderly person revealed symptoms of severe depression (Table 5).

In terms of the institutions surveyed, each had between one and 13 employees, without specialized qualifications, distributed among three shifts (morning, afternoon and night). For weekend shifts, two to four employees were available during the 24 hours of each day. There were two to five health professionals at each institution, with nursing technicians being the most common. It was notable that no institution had contractually hired health professionals, with all such staff volunteers, provided by the local council, or professionals who provided private care to the elderly upon request. Of the 11 institutions, $61.7 \%$ did not have a partnership with a health care provider, but only with hospitals and/or the local health department.

Table 2. Family aspects of elderly residents of Long Term Care Facilities in eight municipal districts (Torres, Três Cachoeiras, Capão da Canoa, Tramandaí, Osório, Cidreira, Santo Antônio da Patrulha and Mostardas) of the north coast of Rio Grande do Sul. Rio Grande do Sul, 2010.

\begin{tabular}{ll}
\hline Variables & $\mathrm{n}(\%)$ \\
\hline Children & $38(63.3)$ \\
No & $22(36.7)$ \\
Yes & $22(100)$ \\
\hline Do children often visit & - \\
Yes & \\
No & $45(75.0)$ \\
Receives other visits & $15(25.0)$ \\
Yes & \\
No & $18(30.0)$ \\
\hline With whom did subject live before entering LTCF? & $16(26.7)$ \\
Alone & $11(18.3)$ \\
Children & $03(5.0)$ \\
Brother(s) or sister(s) & $12(20.0)$ \\
Spouse & \\
Others (friends, grandchildren, domestic staff) & $33(55.0)$ \\
\hline Does subject own their own home? & $27(45.0)$ \\
No & \\
Yes &
\end{tabular}


Table 3. Conditions of morbidity, use of medications and perception of health of elderly residents of Long Term Care Facilities in eight municipal districts (Torres, Três Cachoeiras, Capão da Canoa, Tramandaí, Osório, Cidreira, Santo Antônio da Patrulha and Mostardas) of the north coast of Rio Grande do Sul. Rio Grande do Sul, 2010.

\begin{tabular}{ll}
\hline Variables & $\mathrm{n}(\%)$ \\
\hline Does subject have a health plan? & $45(75.0)$ \\
No & $15(25.0)$ \\
Yes & \\
\hline Main complaint & $23(38.3)$ \\
Difficulty walking & $10(16.7)$ \\
General pain & $08(13.3)$ \\
Vision problems & $06(10.0)$ \\
Generalized fatigue & $04(6.7)$ \\
Memory problems & $03(5.0)$ \\
Shortness of breath & $01(1.7)$ \\
Dizziness & $01(1.7)$ \\
Weight loss & $04(6.7)$ \\
No complaints & \\
Chronic diseases & $55(95.0)$ \\
Yes & $05(5.0)$ \\
No & \\
\hline Use of medications & $55(95.0)$ \\
Yes & $05(5.0)$ \\
No & \\
Perception of general state of health & $06(10.0)$ \\
Excellent & $30(50.0)$ \\
Good & $20(33.3)$ \\
Poor & $04(6.7)$ \\
\hline & \\
\hline
\end{tabular}

Table 4. Functional Capacity of elderly residents of Long Term Care Facilities in eight municipal districts (Torres, Três Cachoeiras, Capão da Canoa, Tramandaí, Osório, Cidreira, Santo Antônio da Patrulha and Mostardas) of the north coast of Rio Grande do Sul. Rio Grande do Sul, 2010.

\begin{tabular}{ll}
\hline Variables & $\mathrm{n}(\%)$ \\
\hline Feeding & $57(95.0)$ \\
Independent & $03(5.0)$ \\
Needs help & \\
\hline Transfers & $46(76.7)$ \\
Independent & $10(16.7)$ \\
Needs help & $04(6.6)$ \\
Dependent & \\
\hline Grooming & $47(78.3)$ \\
Independent & $13(21.7)$ \\
Dependent & \\
\hline Toilet Use & $45(75.0)$ \\
Independent & $15(25.0)$ \\
Dependent & \\
Bathing & $32(53.3)$ \\
Independent & $28(46.7)$ \\
Dependent &
\end{tabular}


Continued from Table 4

\begin{tabular}{lc} 
Walking on flat surface & $36(60.1)$ \\
Walk 50m without help & $17(28.3)$ \\
With help & $05(8.3)$ \\
Wheelchair & $02(3.3)$ \\
Immobile & \\
\hline Climbing stairs & $26(43.3)$ \\
Independent & $23(38.3)$ \\
Needs help & $11(18.3)$ \\
Incapable & \\
Dressing & $38(63.3)$ \\
Independent & $15(25.0)$ \\
Needs help & $07(11.7)$ \\
Incapable & \\
\hline Anal incontinence & $46(76.7)$ \\
Controls sphincter & $11(18.3)$ \\
Incontinent & $03(5.0)$ \\
Requires assistance & \\
Bladder incontinence & $35(58.3)$ \\
Controls sphincter & $14(23.3)$ \\
Incontinent & $11(18.3)$ \\
Requires assistance &
\end{tabular}

Table 5. Classification of elderly residents of Long Term Care Facilities in eight municipal districts (Torres, Três Cachoeiras, Capão da Canoa, Tramandaí, Osório, Cidreira, Santo Antônio da Patrulha and Mostardas) of the north coast of Rio Grande do Sul, according to the Geriatric Depression Scale. Rio Grande do Sul, 2010.

\begin{tabular}{ll}
\hline Geriatric Depression Scale & $\mathrm{n}(\%)$ \\
\hline Moderate depression & $32(53.3)$ \\
Severe depression & $01(1.7)$ \\
No depression & $27(45.0)$ \\
\hline
\end{tabular}

\section{DISCUSSION}

The aging of the global population is an accelerated process of demographic transition, resulting in an important and growing social transformation that increases the demand for LTCFs $^{20}$. The present study described the profile of the institutionalized elderly population of the north coast region of the state of Rio Grande do Sul, and presented a previously uninvestigated research subject.

Predictors for institutionalization are the female gender, advanced age, widowhood, and low levels of education and income ${ }^{5,8}$. There has been found to be a predominance of females among the institutionalized community ${ }^{2,5,8,20}$, corroborating the findings of the present study. There was a predominance of the age range of 70 to 89 years in the sample, with age being a highly oscillating variable in Brazilian $\mathrm{LTCFs}^{20}$. Age itself is not a determining factor of institutionalization, but health conditions are, taking into account functional capacity and the cognitive deficit related to the loss of autonomy and independence ${ }^{21}$.

In the present study, 93 elderly persons (42.6\%) were excluded from the sample due to presenting significant cognitive deficits leading to their inability to properly complete the data collection 
instruments. Studies in $\mathrm{Brazi}^{8,22}$ and other countries $^{23}$ have identified results similar to those described here. One of the reasons for the high prevalence of cognitive deficits found in LTCFs may be the greater need for specialized care of such elderly people, which the vast majority of Brazilian families cannot afford to provide at home. With the aging of the Brazilian population, the trend is that more and more elderly people will suffer cognitive impairment in the near future. Therefore, public policies aimed at the prevention of cognitive loss, as well as the management of elderly people already suffering from the same, should be debated and put into practice to promote old age with a better quality of life.

A low level of schooling was prevalent, mainly due to the difficulties of access to schools in the past ${ }^{20}$, combined with the predominantly agricultural and "homemaker" occupations found in the sample. Illiteracy among the elderly is a reality in developing countries such as Brazil, mainly because such elderly persons spent their childhood in an era in which education was not a priority ${ }^{5}$. Another relevant aspect is the fact that half of the elderly persons are from rural parts of the state, where the number of schools was very low and access to the same very difficult ${ }^{24}$.

Most of the participants did not have partners or children, a result similar to a study carried out in Belo Horizonte, in the state of Minas Gerais ${ }^{25}$. This may be another factor that leads elderly persons to reside in $\mathrm{LTCFs}^{3,26}$.

A study of elderly people living in LTCFs in Brasilia, in the Distrito Federal (Federal District), observed that half of such individuals received visits from their relatives ${ }^{26}$. In Singapore, a significant proportion of elderly residents (82.4\%) were visited by their relatives, friends, and volunteers ${ }^{27}$. The findings of the present study, where $75 \%$ of the elderly received visits, are corroborated by such surveys. This large number of elderly people receiving visits shows that the family is concerned and cares about such individuals, contradicting questions regarding the abandonment of such individuals. This result is significant as the non-abandonment of the elderly in LTCFs by their network of relationships contributes to such individuals presenting better health conditions and improved adaptation and participation in the proposed activities. These findings contribute to support actions that integrate families with the care routine that LTCFs establish for their elderly residents.

In terms of the morbidity of the elderly, studies have found a high frequency of chronic diseases and use of medication among institutionalized individuals ${ }^{25,26,28,29}$, results similar to those of the present study. Half of the participants self-reported their health as good, while about one-third described their health status as fair. Similar data have been found in other studies ${ }^{5,25,28}$. It is important to identify the self-rated health of the population as the perception of negative health is described in literature as a predictor of mortality, functional disability and the mental health of the elderly ${ }^{30}$.

Few elderly patients described generalized pain. However, other studies have described a high prevalence of chronic pain among institutionalized elderly persons, and its negative relation with the perception of quality of life. Other health complaints reported by institutionalized elderly people from the north coast of Rio Grande do Sul were difficulty walking and vision problems, which are related to the independence and autonomy of functional capacity. The investigation of pain, the presence of depression and independence in activities of daily living are fundamental to determining the measures necessary to promote the health and well-being of the geriatric population ${ }^{31}$.

For the most part, the elderly were considered functionally independent. Among the individuals in the present study, independent feeding was the capacity with the highest percentage of independence $(95 \%)$, while bathing was the most dependent category (46.7\%), findings corroborated by another study that used the Katz Index ${ }^{25}$. There are reports in literature that identify a clear relationship between institutionalization and a decrease in autonomy and perception of quality of life among the elderly after 12 months of living in the institution ${ }^{32}$.

The changes experienced by elderly persons, such as loss of a partner, illness, physical dependence and institutionalization may be the starting point 
for psychic disorders ${ }^{22}$. It is at this time that depression appears as a significant health problem for the elderly, with the psychiatric syndrome being more prevalent ${ }^{14,19}$.

In this study, despite the fact that most of the elderly persons were considered to be functionally independent and reported a health status of good, a profile of depression was identified in $53.3 \%$ of individuals. This apparent contradiction between functional independence and the presence of depressive symptomatology has also been reported by other authors ${ }^{25,33}$. This can be explained by the fact that depression has associated risk factors, such as a residence period of over 24 months, a history of known depression, pain, the absence or shortage of social contact and difficulty communicating with caregivers ${ }^{27}$. Being physically independent does not necessarily mean the absence of depressive symptoms. The scenario found in the LTCFs of the north coast of Rio Grande do Sul, which feature elderly people with low educational levels and monthly incomes and high rates of chronic diseases, may also contribute to the rates of depression presented in this study. The combination of the absence of children, low purchasing power, the morbidity rates observed, difficulty in carrying out activities of daily living, and distance from or absence of family can lead the elderly to social isolation, institutionalization and depression ${ }^{20,26,34}$.

One possible limitation of the study would be that, in addition to cognitive deficit, the general health situation at the time of data collection restricted the sample size. As a result, it was not possible to describe reliable correlations between the studied variables, which explains the descriptive design of this work. The absence of correlation analysis limits possible inferences but the presented data allows the characteristics of the LTCFs and their residents to be identified.

\section{REFERENCES}

1. Prado SD, Sayd JD. A pesquisa sobre envelhecimento humano no Brasil: grupos e linhas de pesquisa. Ciênc Saúde Coletiva. 2008;9(1):57-68.

\section{CONCLUSION}

The present study described the sociodemographic profile, the health situation and the degrees of functionality and depression of institutionalized elderly people in the north coast of the state of Rio Grande do Sul in Brazil.

The majority of the institutionalized elderly were women, and the predominant age group was between 70 and 89 years old. Most of the participants had low incomes and schooling levels, did not have spouses and were white/Caucasian. Although the majority did not have children, they received frequent visits. In terms of health, the present study identified a greater percentage of elderly people with chronic diseases, who used medications, and did not have a health plan. More than half of the elderly individuals, however, considered their health to be good or excellent. Although the elderly studied presented good results in functional capacity analysis, many were classified as suffering from depression.

The magnitude and severity of the issues identified in this study constitute a challenge for health services when tackling these problems, due to the shortage of qualified professionals and the lack of a formal support network for Long Term Care Facilities for the Elderly (LTCFs).

This study contributes to the basis for the elaboration of policies that address the working conditions, the services offered and the training of professionals so that the elderly person feels welcomed, respected and safe. It is essential to expand and deepen research that encompasses the elderly in conditions of institutionalization, especially in terms of depression. The health of the elderly is a vast area in terms of the production of knowledge that can contribute to public health policies, as well as to the practices of health professionals in LTCFs.

2. De Oliveira PB, Dos Santos DMT. Condições de saúde de idosos residentes em instituição de longa permanência segundo necessidades humanas básicas. Rev Bras Enferm. 2014;67(2):241-6. 
3. Oliveira JM, Rozendo CA. Instituição de longa permanência para idosos: um lugar de cuidado para quem não tem opção? Rev Bras Enferm. 2014;67(5):773-9.

4. Silva ME, Cristianismo RS, Dutra LR, Dutra IR. Perfil epidemiológico, sociodemográfico e clínico de idosos institucionalizados. Rev Enferm Cent.-Oeste Min. 2013;3(1):569-76.

5. Borges AM, Santos G, Kummer JA, Fior L, Molin VD, Wibelinger LM. Autopercepção de saúde em idosos residentes em um município do interior do Rio Grande do Sul. Rev Bras Geriatr Gerontol. 2014;17(1):79-86.

6. Pilger C, Menon MH, Mathias TAF. Características sociodemográficas e de saúde de idosos: contribuições para os serviços de saúde. Rev Latinoam Enferm. 2011;19(5):1230-8.

7. Duarte E, Marques A, Leal M, Melo GP, Silva C. Idosos diabéticos autopercepção do estado geral de saúde. In: Anais do $4^{\circ}$ Congresso Ibero-Americano em Investigação Qualitativa; 5-7 ago. 2015; Aracaju. Aracaju: Universidade Tiradentes; 2015. p. 288-90. V. 1: Investigação qualitativa na saúde.

8. Dantas CMDHL, Bello FA, Barreto KL, Lima LS. Capacidade funcional de idosos com doenças crônicas residentes em Instituições de Longa Permanência. Rev Bras Enferm. 2013;66(6):914-20.

9. De Azevedo LM, De Oliveira KMV, Nunes VMA, Alchieri JC. Perdas da capacidade funcional em idosos institucionalizados no município de Natal/RN. Rev Pesqui Cuid Fundam. 2014;6(2):485-92.

10. Pagotto V, Silva VAP, Pereira LV, Santos DPMA. Comparação da funcionalidade de idosos residentes em duas modalidades institucionais. Rev Eletr Enferm [Internet]. 2016 [acesso em 01 jun. 2016];18:1143. Disponível em: http://dx.doi. org/10.5216/ree.v18.34712

11. Silva JKSD, Albuquerque MCDS, Souza EMSD, Monteiro FS, Esteves GGL. Sintomas depressivos e capacidade funcional em idosos institucionalizados. Cult Cuid. 2015;41:157-67.

12. Alencar MA, Bruck NNS, Pereira BC, Câmara TMM, Almeida RDS. Perfil dos idosos residentes em uma instituição de longa permanência. Rev Bras Geriatr Gerontol. 2012;15(4):785-96.

13. Santiago LM, Mattos IE. Sintomas depressivos em idosos institucionalizados. Rev Saúde Pública. 2014;48(2):216-24.

14. Nóbrega IRAP, Leal MCC, Marques APO, Vieira JCM. Fatores associados à depressão em idosos institucionalizados : revisão integrativa. Saúde Debate. 2015;39(105):536-50.
15. Leal MCC, Apóstolo JLA, Mendes AMOC, Marques APDO. Prevalência de sintomatologia depressiva e fatores associados entre idosos institucionalizados. Acta Paul Enferm. 2014;27(3):208-14.

16. Frade J, Barbosa P, Nunes C. Depression in the elderly: symptoms in institutionalised and non-institutionalised individuals. Rev Enferm Ref. 2015;4(4):41-8.

17. Bertolucci PHF, Bruck SMD, Campacci SR. O miniexame do estado mental. Impacto da escolaridade. Arq Neuropsiquiatr. 1994;52(1):1-7.

18. Ribeiro M, Miyazaki MH, Sakamoto H, Pinto PPN, Battistella LR. Validação da versão brasileira da medida de independência funcional. Acta Fisiátrica. 1988;11(2):72-6.

19. Almeida OP, Almeida AS. Confiabilidade da versão brasileira da escala de depressão em geriatria (GDS) versão reduzida. Arq Neuropsiquiatr. 1999;57(2B):421-6.

20. Lisboa CR, Chianca TCM. Perfil epidemiológico, clínico e de independência funcional de uma população idosa institucionalizada. Rev Bras Enferm. 2012;65(3):482-7.

21. Vivan AS, Argimon IIL. Estratégias de enfrentamento, dificuldades funcionais e fatores associados em idosos institucionalizados. Cad Saúde Pública. 2010;25(2):436-44.

22. Reis LA, Araújo CC, Novaes LKN. Rastreamento cognitivo de idosos institucionalizados no município de Jequié-BA. Psicol Estud. 2010;14(2):295-301.

23. Rebouças M, Pereira MG. Indicadores de saúde para idosos: comparação entre o Brasil e os Estados Unidos. Rev Panam Salud Publica. 2008;23(4):237-46.

24. Guedes JM, Silveira RC. Análise da capacidade funcional da população geriátrica institucionalizada na cidade de Passo Fundo-RS. Rev Bras Ciênc Envelhec Hum 2008;1(2):10-21.

25. Alencar MA, Bruck NN, Pereira BC, Câmara TMM, Almeida RDS. Perfil dos idosos residentes em uma instituição de longa permanência. Rev Bras Geriatr Gerontol. 2012;15(4):785-96.

26. Oliveira MPF, Novaes MRCG. Perfil socioeconômico, epidemiológico e farmacoterapêutico de idosos institucionalizados de Brasília, Brasil. Ciênc Saúde Coletiva 2013;18(4):1069-78.

27. Tiong WW, Yap P, Huat Koh GC, Phoon Fong N, Luo N. Prevalence and risk factors of depression in the elderly nursing home residents in Singapore. Aging Ment Health 2013;17(6):724-31.

28. Gonçalves LG, Vieira ST, Siqueira FV, Hallal PC. Prevalência de Quedas em Idosos Asilados do Município de Rio Grande, RS. Rev Saúde Pública. 2008;42(5):938-45. 
29. Silva SA, Scazufca M, Menezes P. Population impact of depression on functional disability in elderly: Results from "São Paulo Ageing \& Health Study" (SPAH). Eur Arch Psychiatr Clin Neurosci. 2013;263(2):153-8.

30. Balboa-Castillo T, León-Muñoz LM, Graciani A, Rodríguez-Artalejo F, Guallar-Castillón P. Longitudinal association of physical activity and sedentary behavior during leisure time with healthrelated quality of life in community dwelling older adults. Health Qual Life Outcomes [Internet]. 2011 [acesso em 22 dez. 2015];9:47. Disponível em: http:// www.hqlo.com/ content/9/1/47

31. Tarakci E, Zenginler Y, Kaya-Mutlu E. Chronic pain, depression symptoms and daily living independency level among geriatrics in nursing home. Agri 2015;27(1):35-41.

Received: March 22, 2016

Reviewed: October 13, 2016

Accepted: March 22, 2017
32. Cobo CMS. The influence of institutionalization on the perception of autonomy and quality of life in old people. Rev Esc Enferm USP. 2014;48(6):1013-9.

33. Nascimento DC, Brito MAC, Santos AD. Depressão em idosos residentes em uma instituição asilar na cidade de Juazeiro do Norte, Ceará, Brasil. J Manag Prim Health Care. 2013;4(3):146-50.

34. Danilow MZ, Moreira ACS, Vilela CG, Barra BB, Novaes MRCG, Oliveira MPF. Perfil epidemiológico, sociodemográfico e psicossocial de idosos institucionalizados do Distrito Federal (DF). Comun Ciênc Saúde. 2010;18 (1):9-16. 